\title{
Editorial
}

Dermatology

Published online: April 24, 2010

DOI: $\underline{10.1159 / 000278229}$

\section{Giant Melanocytic Nevus May Be Explained as a Superimposed Patchy Manifestation of a Polygenic Trait}

\author{
Rudolf Happle \\ Department of Dermatology, University Medical Center, Freiburg, Germany
}

\section{Key Words}

Giant melanocytic nevus - Common melanocytic nevi •

Polygenic inheritance $\cdot$ Early postzygotic mutation $\cdot$ Mosaic manifestation, superimposed

\section{Introduction}

Giant melanocytic nevi (GMN), defined as congenital lesions measuring $20 \mathrm{~cm}$ or more in diameter at adult age [1], are important because of the cosmetic burden, a frequently associated leptomeningeal melanocytosis, and an inherent risk of malignant melanoma [2]. The incidence of GMN is about 1 in 20,000 live births [3]. They usually occur sporadically but may exceptionally also show a familial aggregation. To explain this paradox, the concept of paradominant inheritance has been proposed [2].

The etiology of GMN is still unknown. Here, arguments are presented in favor of the assumption that GMN represent a superimposed patchy manifestation of a polygenic trait. This common phenotype consists of multiple small disseminated melanocytic nevi that are either present at birth or appear later in life.

\section{KARGER}

Fax +4161306 1234

E-Mail karger@karger.ch

www.karger.com
(C) 2010 S. Karger AG, Basel

$1018-8665 / 10 / 2211-0030 \$ 26.00 / 0$

Accessible online at: www.karger.com/drm

\section{Coexistence of GMN and Small Disseminated Melanocytic Nevi}

Cases of GMN associated with small disseminated nevi involving the entire body have been documented with historical figures published in many articles and textbooks [4-9] and have also been reported in more recent publications [10-13]. So far, the associated small nevi have usually been categorized as 'satellite lesions' [4, 12 , 13]. Admittedly, true satellite lesions are often noted. As a rule of thumb, such satellite nevi tend to be found within a $15-\mathrm{cm}$ zone surrounding a GMN, which is reminiscent of an archipelago. By contrast, a scattered distribution all over the body (fig. 1,2) suggests that in such cases the associated small nevi should rather be taken as disseminated 'background lesions'. These common small melanocytic nevi do not mendelize but represent a polygenic trait [14-16]. Specifically, recent molecular research has shown that both congenital and acquired small melanocytic nevi have a common polygenic background, including mutations at the loci of BRAF, N-ras, MC1R and p53 [17-20]. 

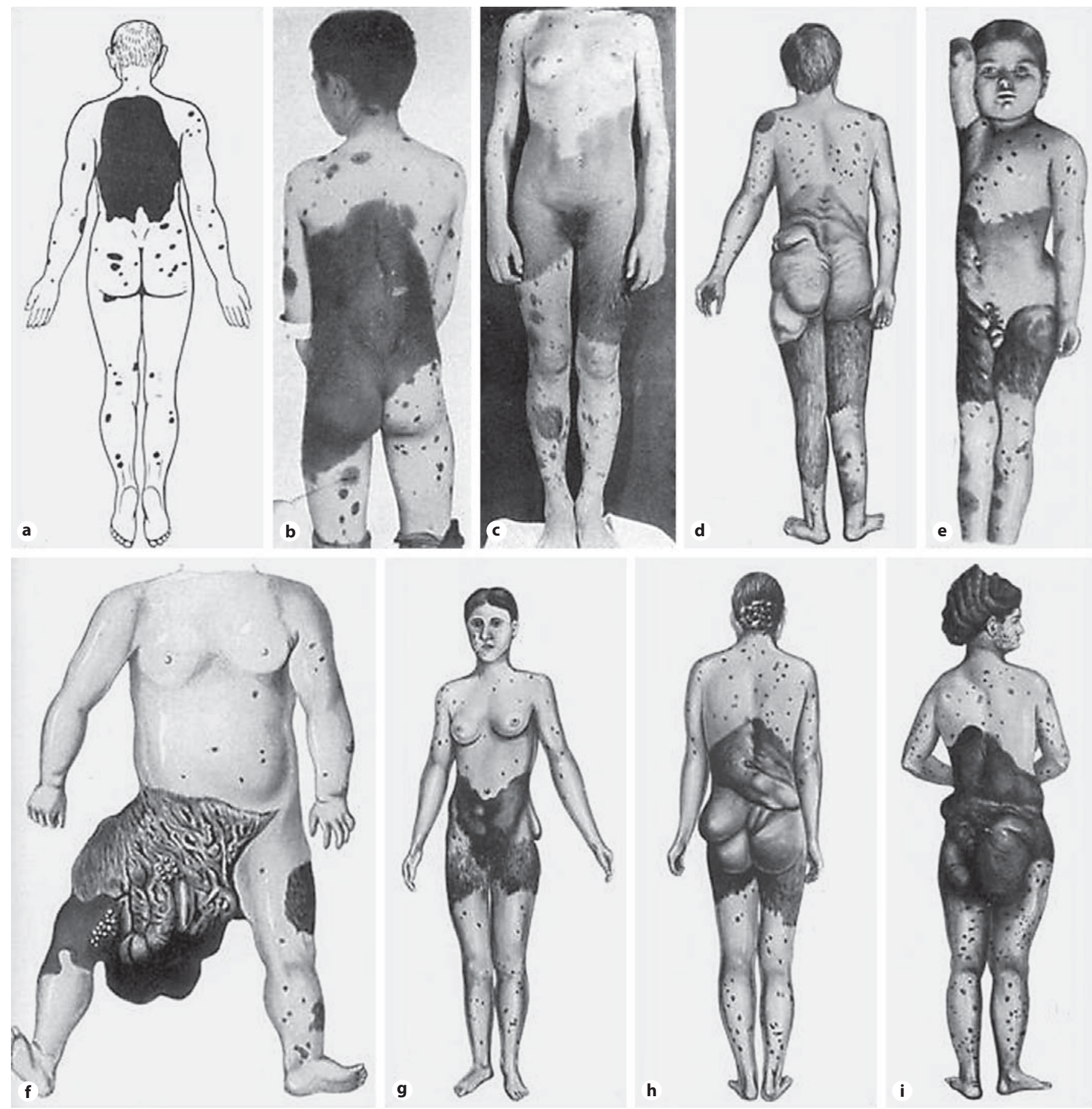

Fig. 1. Historical cases of GMN superimposed on small disseminated nevi. a Siemens and Waardenburg [4]. b Arzt and Fuhs [5]. c Sutton and Sutton [6]. Cases reviewed by Meirowsky [7]: Reinhardt, 1895 (d), Fox, 1912 (e), von Planner, 1887 (f), Reinhardt, 1895 (g, h), and De Amicis 1875/1876 (i). 
Fig. 2. 22-year-old woman with GMN and numerous small disseminated nevi: frontal aspect (a) and dorsal aspect (b) [reprinted with permission, 8].
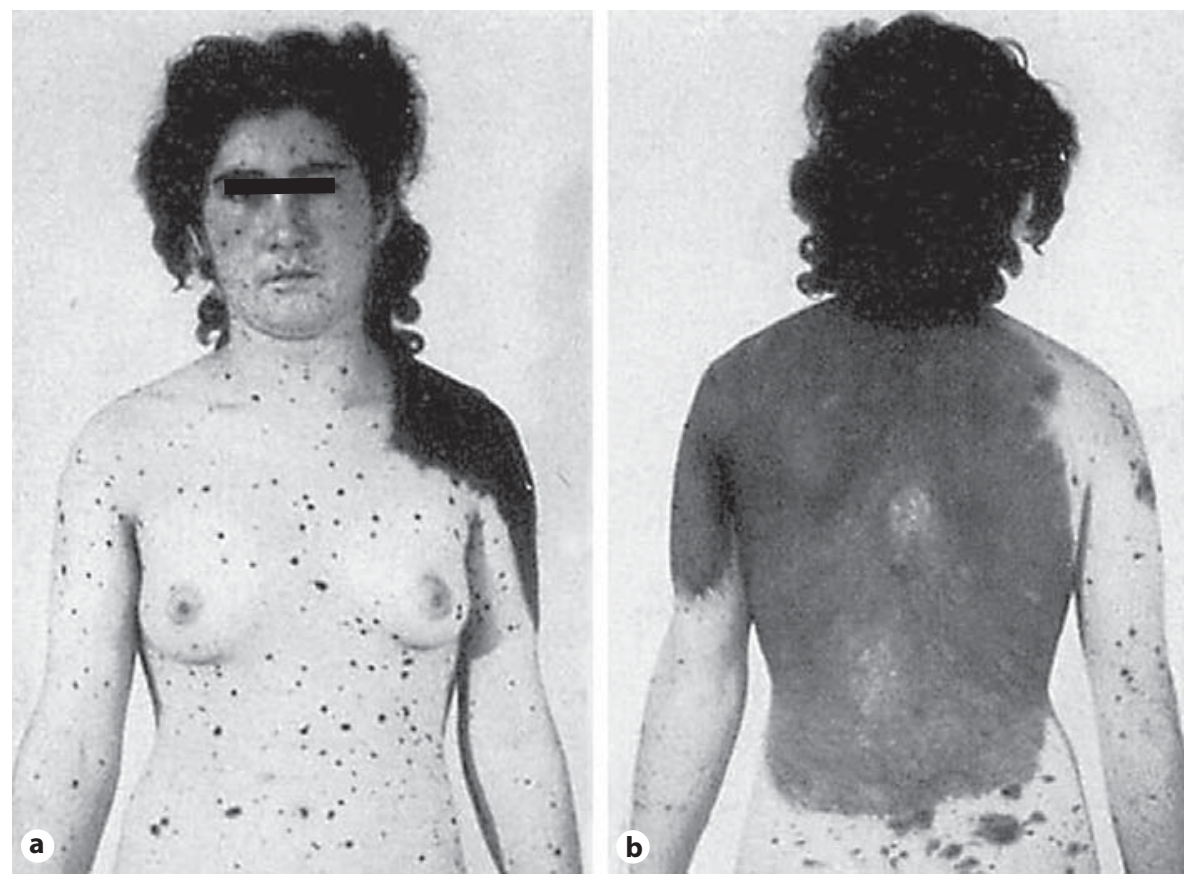

\section{The Proposed Concept of Superimposed Patchy Manifestation}

Common cutaneous traits with a polygenic predisposition, such as psoriasis, atopic dermatitis, or vitiligo, may sometimes manifest themselves in a pronounced linear, flag-like, or otherwise mosaic arrangement. These mosaic lesions are often associated with a less severe, nonsegmental involvement and, therefore, the term 'superimposed segmental manifestation' has been proposed [21]. This type of mosaicism results either from loss of heterozygosity involving one of the predisposing genes or from a postzygotic mutation giving rise to heterozygosity at an additional predisposing gene locus. In 2009, examples of such superimposed segmental manifestation included 15 different polygenic skin disorders [22, 23].

By analogy, GMN can be taken as an additional disorder exemplifying this mechanism. For obvious reasons, however, the term 'segmental' is not always appropriate in this particular mosaic disorder (see, for example, fig. 1a, h, i, 2b). Rather, the designation 'superimposed patchy manifestation' or the less specific term 'superimposed mosaic involvement' can be applied to GMN.

\section{Do Cases of Isolated GMN Result from a Similar Mechanism?}

At this point in time it seems conceivable that a similar explanation can be applied to cases of isolated GMN. In such cases, the disseminated small nevi may develop later in life, or the polygenic predisposition, although present, may be too weak to develop a high number of common small lesions.

\section{Is GMN Associated with a Familial Occurrence of Disseminated Small Melanocytic Nevi?}

In family members of patients with GMN, an increased number of small melanocytic nevi has been reported [24]. In most cases of GMN, however, the presence of many small melanocytic nevi in relatives may so far have gone unnoticed. In future studies, special attention should be paid to this question.

\section{Conclusion}

According to the proposed concept, GMN and common small melanocytic nevi harbor similar mutations because they originate from the same polygenic predis- 
position. The only difference would be that the postzygotic mutational event giving rise to GMN happens at an early stage of embryogenesis, whereas in the smaller nevi this mutational step would occur at a later developmental stage or during postnatal life.

The concept of superimposed GMN would explain why the affected newborn children often show, in addition, multiple small nevi scattered over their entire body; why they tend to develop additional small nevi during postnatal life; why family members most likely have increased numbers of small melanocytic nevi; and why GMN usually occurs sporadically but may exceptionally involve several members of a family.

In future reports on GMN, clinicians should discriminate between true satellite lesions and the presence of disseminated 'background' nevi as reviewed in the present article.

\section{References}

1 Consensus conference: precursors to malignant melanoma. JAMA 1984;251:1864-1866.

$\checkmark 2$ Danarti R, König A, Happle R: Large congenital melanocytic nevi may reflect paradominant inheritance implying allelic loss. Eur J Dermatol 2003;13:430-432.

$\checkmark 3$ Castilla EE, da Graça Dutra M, Orioli-Parreiras IM: Epidemiology of congenital pigmented naevi. I. Incidence rates and relative frequencies. Br J Dermatol 1981;104:307315.

4 Siemens HW, Waardenburg PJ: Über ausgedehnte bilaterale Tierfellnaevi bei dem einen von zwei eineiigen Zwillingsbrüdern. Arch Dermatol Syph 1927;153:145-156.

5 Arzt L, Fuhs H: Gutartige Neubildungen der Haut; in Arzt L, Zieler K (eds): Die Haut- und Geschlechtskrankheiten: eine zusammenfassende Darstellung für die Praxis. Berlin, Urban \& Schwarzenberg, 1935, vol 2, pp 975 1164.

6 Sutton RL, Sutton RL Jr: Handbook of Diseases of the Skin. St Louis, Mosby, 1949, p 576.

7 Meirowsky E: Idiotypische Pigmentanomalien; in Jadassohn J (ed): Handbuch der Haut- und Geschlechtskrankheiten. Berlin, Springer, 1933, vol IV/2, pp 588-795.

$>8$ Steinmetz R: Naevus géant pigmentaire, pileux et hyperkératosique (Tierfellnaevus) et naevi pigmentaires et pileux généralisés. Dermatologica 1947;94:178.
Musger A: Melano-Phakomatosen. 1. Melanophakomatose vom Typus der sog. Mélanoblastose neuro-cutanée Touraine. Hautarzt 1963;14:106-110.

10 Gross PR, Carter DM: Malignant melanoma arising in a giant cerebriform nevus. Arch Dermatol 1967;96:536-538.

11 Rompel R, Meyer W, Petres J: Zerebriformer intradermaler Nävus. Hautarzt 1993; 44:238-241.

12 Schaffer JV, McNiff JM, Bolognia JL: Cerebral mass due to neurocutaneous melanosis: eight years later. Pediatr Dermatol 2001;18: 369-377.

13 de Wijn RS, Zaal LH, Hennekam RC, van der Horst CM: Familial clustering of giant congenital melanocytic nevi. J Plast Reconstr Aesthet Surg 2009, E-pub ahead of print.

14 Siemens HW: Die Zwillingspathologie: ihre Bedeutung, ihre Methode, ihre bisherigen Ergebnisse. Berlin, Springer, 1924, pp 24-25, 47-48.

15 Happle R: Gregor Mendel und die dysplastischen Nävi. Hautarzt 1989;40:70-76.

16 Uribe P, Wistuba II, Gonzalez S: Allelotyping, microsatellite instability, and $B R A F \mathrm{mu}$ tation analyses in common and atypical melanocytic nevi and primary cutaneous melanomas. Am J Dermatopathol 2009;31: 354-363.

17 Papp T, Pemsel H, Zimmermann R, Bastrop R, Weiss DG, Schiffmann D: Mutational analysis of the $N$-ras, p53, p16 $6^{I N K 4 a}, C D K 4$, and MC1R genes in human congenital melanocytic naevi. JMed Genet 1999;36:610-614.
8 Pollock PM, Harper UL, Hansen KS, Yudt LM, Stark M, Robbins CM, Moses TY, Hostetter G, Wagner U, Kakareka J, Salem G, Pohida T, Heenan P, Duray P, Kallioniemi O, Hayward NK, Trent JM, Meltzer PS: High frequency of $B R A F$ mutations in nevi. Nat Genet 2003;33:19-20.

19 Papp T, Schipper H, Kumar K, Schiffmann D, Zimmermann R: Mutational analysis of the BRAF gene in human congenital and dysplastic melanocytic naevi. Melanoma Res 2005;15:401-407.

20 Ichii-Nakato N, Takata M, Takayanagi S, Takashima S, Lin J, Murata H, Fujimoto A, Hatta N, Saida T: High frequency of $B R A F^{V 600 E}$ mutation in acquired nevi and small congenital nevi, but low frequency of mutation in medium-sized congenital nevi. J Invest Dermatol 2006;126:2111-2118.

21 Happle R: Superimposed segmental manifestation of polygenic skin disorders. J Am Acad Dermatol 2007;57:690-699.

$\checkmark 22$ Happle R: Superimposed segmental manifestation of both rare and common cutaneous disorders: a new paradigm. Actas Dermosifiliogr 2009;100(suppl 1):77-85.

23 Happle R: Superimposed segmental hemangioma of infancy. Dermatology 2010;220: 180-182.

24 Russel J, Reyes RG: Giant pigmented nevi. JAMA 1959;171:2083-2086. 